\title{
Educação escolar indígena: a escola e os velhos no ensino da história kaingang
}

Indigenous school education: the school and the elderly in the teaching of Kaingang history

Juliana Schneider Medeiros*

\section{RESUMo}

A educação escolar indígena específica e diferenciada vem sendo construída por diversos povos indígenas do país desde a promulgação da Constituição Federal (1988), marco de sua conquista pelo direito à diferença. $\mathrm{O}$ artigo apresenta resultados de uma pesquisa de mestrado baseada em uma etnografia dos Kaingang da Terra Indígena Guarita (Rio Grande do Sul), tendo como cenário principal a escola indígena Toldo Campinas, no setor Estiva. Com base nas aulas de História e nas conversas com os velhos, apresentam-se reflexões sobre a relação dos velhos com a escola, buscando entender qual o papel desses 'contadores de histórias' na transmissão da história kaingang.

Palavras-chave: educação escolar indígena; escola kaingang; ensino de História.

\section{Abstract}

The specific and differentiated indigenous school education has being developed by various indigenous peoples of Brazil since the Federal Constitution promulgation (1988), landmark in the conquest of their right to be different. This paper presents the results of a Master's research through the ethnography of a Kaingang community in the Guarita Indigenous Reservation (Rio Grande do Sul), in which the main setting for the study was the indigenous school Toldo Campinas, in the Estiva sector. Based on the History classes and on talks with the elderly, this study presents a discussion on the relationship between the elderly and the school, trying to understand the role of these 'story tellers' in transmitting the kaingang history.

Keywords: indigenous school education; Kaingang school; History teaching.

A educação escolar é hoje uma realidade para milhares de indígenas no Brasil. A maioria das Terras Indígenas (TI) do país possui escolas onde suas crianças estudam diariamente. Números atuais referentes ao estado do Rio

*Núcleo de Pesquisa em Educação Indígena da UFRGS. Faculdade de Educação/UFRGS, Prédio 12201, Av. Paulo Gama, s/n. 90046-900 Porto Alegre - RS - Brasil. jusmedeiros@yahoo.com.br 
Grande do Sul, onde se realizou a pesquisa, apresentam 6.327 estudantes em 78 escolas. ${ }^{1}$ A atual escola indígena pretende-se uma escola dos povos indígenas, pensada e construída por eles com base em seus anseios e suas necessidades. Porém, nem sempre foi assim. O contato dos povos indígenas com a educação escolar remonta ao período colonial, quando missionários jesuítas vieram às Américas com o intuito de conquistar novos fiéis para a Igreja católica. Ao longo de toda a história do país, a escolarização dos indígenas, dirigida ora por ordens religiosas ora pelo Estado, teve como objetivos principais civilizá-los e prepará-los para o trabalho. Do modo como ela funcionou até recentemente, esteve a serviço do assimilacionismo e contribuiu para desarticular os modos de vida indígenas e aniquilar as línguas nativas.

Nos anos 1970, inserida em um movimento de luta pela demarcação das terras indígenas e pelo reconhecimento e preservação das diferenças étnicas, a educação escolar indígena passou a ser tema de encontros e discussões que sistematizaram o que viria a constar futuramente na legislação específica referente à escola indígena. ${ }^{2}$ Foi esse momento de intensos debates, ao final da ditadura militar, que possibilitou a forte atuação dos indígenas na Assembleia Constituinte e abriu uma nova fase para a educação escolar indígena, com a aprovação da Constituição de 1988. Muitos direitos importantes foram conquistados, como o direito à diferença, que pôs fim à política assimilacionista do Estado, garantindo legalmente aos povos indígenas o respeito à sua organização social, a costumes, línguas, crenças e tradições, e o direito a uma educação específica e diferenciada, ao reconhecer o uso de línguas maternas e processos próprios de aprendizagem. ${ }^{3}$ A partir daí desencadeou-se um movimento de afirmação da educação escolar indígena, por meio de leis, da criação de setores específicos para a gestão dessa modalidade de escola e do envolvimento de lideranças, professores e intelectuais indígenas na condução desse processo.

De acordo com essa nova legislação, a escola indígena deve ser comunitária, intercultural, bilíngue, específica e diferenciada. ${ }^{4}$ Comunitária, porque a participação da comunidade em todo o processo pedagógico é fundamental para a construção da escola: na definição dos objetivos, dos conteúdos curriculares, do calendário escolar, da pedagogia, dos espaços e momentos da educação escolar. Intercultural, pois a escola deve reconhecer e manter a diversidade cultural e linguística de sua comunidade, além de promover uma situação 
de comunicação entre experiências socioculturais, linguísticas e históricas diferentes. Bilíngue, visto que deve ensinar o português, para possibilitar o diálogo com o mundo não indígena que os rodeia, mas, principalmente, a língua materna da comunidade indígena - para garantir a sua manutenção e, sobretudo, porque é por meio da língua originária que se expressa e se manifesta a cultura. Específica e diferenciada, porque deve ser concebida e planejada como reflexo das aspirações particulares de cada povo indígena e com autonomia em relação à construção de sua escola. A maioria dos povos indígenas hoje vê a escola como uma aliada: para aprender os códigos do 'mundo dos brancos' (tendo como principal exemplo a aquisição da língua portuguesa), de modo a se instrumentalizar para as lutas indígenas; e também para tentar reverter o processo de ocidentalização e desestruturação cultural que sofreram até então, fortalecendo suas culturas.

As reflexões apresentadas neste artigo resultam de uma pesquisa de mestrado realizada com os Kaingang da Terra Indígena Guarita com base em uma descrição densa $a^{5}$ que teve como cenário principal a escola indígena Toldo Campinas, no setor Estiva. A TI Guarita está localizada no norte do estado do Rio Grande do Sul, nos municípios de Tenente Portela, Redentora e Erval Seco, distante cerca de 500 quilômetros de Porto Alegre. A TI está organizada em 12 setores que se distribuem ao longo de mais de 23 mil hectares de terra. Nela vivem 5.397 pessoas, ${ }^{6}$ sendo uma parte minoritária delas Guarani. Os Kaingang dessa região estabeleceram contato permanente com os não índios em meados do século XIX, quando uma frente de expansão invadiu seus territórios tradicionais. A partir daí sua história foi marcada por constantes tentativas de dominação, exploração e ocidentalização. Depois de séculos de uma política indigenista integracionista e de uma escola que tinha por objetivo destruir os modos de vida indígenas e torná-los civilizados, partícipes de um projeto ora colonial, ora imperial, ora nacional, os Kaingang buscam construir uma escola diferente, que valorize sua cultura, sua língua, seu modo de vida e sua história.

A pesquisa teve como foco principal o ensino de História na escola kaingang. Procurei descobrir que história se ensina na escola Toldo Campinas, onde o professor é indígena. Ensina-se a história kaingang? O professor leva as narrativas tradicionais para a escola? Os mais velhos têm algum papel no ensino de História na escola? Apresento aqui reflexões sobre a relação dos 
velhos com a escola, buscando entender qual o papel desses 'contadores de histórias' na transmissão do passado kaingang às novas gerações frequentadoras da escola.

\section{As AULAS DE HISTÓRIA}

De acordo com o Regimento Coletivo das Escolas Estaduais Indígenas Kaingang (2003) a escola indígena deve valorizar as tradições e as histórias kaingang, com o intuito de afirmar sua identidade étnica. Isso pode ser constatado neste trecho: "Nesta perspectiva, a escola busca o resgate histórico-cultural das comunidades, visando a valorização da cultura e das leis internas da comunidade, para garantir ao nosso povo o direito de ser diferente do não índio e também a manutenção de nossos costumes". ${ }^{7}$ Esse documento não menciona diretamente a matéria de História como responsável por esse 'resgate histórico-cultural'. Os planos de estudos de História da escola Toldo Campinas, no entanto, apresentam temas kaingang em seus conteúdos. Alguns exemplos são: As relações dos Kaingang com o poder público nos séculos XVIII-XIX; A ocupação do território Kaingang pela sociedade luso-brasileira; As demarcações e retomadas de terras das comunidades Kaingang; Guerra da coroa portuguesa contra os Kaingang e os Xokleng; Rota para as missões: penetração paulista no Alto Uruguai no século XIX.

O acompanhamento das aulas de História do professor indígena Lairton Melo, principalmente das exposições e das atividades propostas por ele, permitiu constatar que as histórias kaingang são apenas tangenciadas na escola e que a maioria dos temas relacionados diretamente aos Kaingang previstos nos planos de estudos não é abordada em aula. De modo geral, o que se ensina nas aulas de História é o conteúdo do livro didático. Em entrevista questionei o professor indígena Bruno Ferreira, coordenador pedagógico da escola Toldo Campinas e professor de História em uma escola de outro setor: "O que se ensina na matéria de História?". "No jeito que está só ensinam o que tem no livro didático; não se ensina além disso", respondeu-me o professor. "Então na matéria de História não se trata dos Kaingang nunca?” interroguei outra vez. "Não se trata dos Kaingang! ... Os professores não estão preparados para fazer isso, eles não conhecem isso, na verdade". 
Em primeiro lugar, é preciso destacar que os temas kaingang ainda não constituem conteúdos escolares das escolas não indígenas e, por isso, não há materiais disponíveis em que os professores possam se basear para planejar suas aulas. As escolas indígenas, em geral, disponibilizam aos professores apenas os livros didáticos comuns às escolas não indígenas do país. Esses livros geralmente apresentam uma única versão da história e desconhecem as histórias dos diferentes povos indígenas do Brasil. Apesar dos avanços nas pesquisas historiográficas nos últimos 20 anos e da incorporação de muitos deles aos livros escolares, a apresentação de uma versão escrita oficial da história nacional se mantém, desconsiderando as diferentes formas de memória e de transmissão de histórias.

Isso significa que trabalhar com temas da história kaingang depende muito do próprio professor e de sua formação. Ou seja, se ele não possui formação específica para professor indígena, irá reproduzir o modelo de aula que ele próprio vivenciou enquanto estudante de escolas/universidades não indígenas, onde aprendeu os 'legítimos conhecimentos escolares'. Cursos específicos para indígenas, além de apresentarem uma historiografia mais atualizada sobre os Kaingang - em geral não trabalhada em cursos para não índios - procuram instrumentalizar esses professores a pensarem a história de uma forma diferenciada e a perceberem a importância dos conhecimentos e das memórias tradicionais. Esses cursos visam estimular que os professores busquem o diálogo com a comunidade para que ela lhes ensine a história que não está nos livros. Sem o contato com essa bibliografia diferenciada, mas principalmente com as histórias e as tradições contadas pelos velhos, as aulas continuarão reproduzindo a história do livro didático, embora o professor seja indígena.

A pesquisa demonstrou, no entanto, que há uma vontade e uma disposição do professor Lairton em abordar a história dos povos indígenas e dos Kaingang e que, por vezes, ele encontra frestas por onde insere elementos dessas histórias. Um exemplo disso é a clara predominância do estudo do período colonial, abordado no $6^{\circ}, 7^{\circ}$ e $8^{\circ}$ ano. Acredito ser esse um indício da preocupação do professor em trabalhar a ruptura que ocorreu no modo de vida tradicional dos povos indígenas quando da chegada dos europeus à América - embora o contato dos Kaingang com os não indígenas de forma mais permanente tenha se dado somente a partir da metade do século XIX. É recorrente o uso de quadros comparativos entre o antes e o depois do contato e de 
expressões como 'a chegada dos brancos', 'o descobrimento', 'os 500 anos'. Observei também que o professor busca constantemente incluir os 'índios' em sua narrativa histórica, mesmo quando não fazem parte do conteúdo que está sendo trabalhado. Em uma aula do $8^{\circ}$ ano, em que o tema era o ciclo da cana-de-açúcar e a introdução da mão de obra africana, o professor mencionou os 'índios' diversas vezes: os 'índios' já estavam no Brasil quando os portugueses chegaram e assim foram designados pelos colonizadores, 'porque achavam que era tudo igual'; os 'índios' estabeleceram relações de escambo nos primeiros anos de contato; os 'índios' foram os primeiros trabalhadores dos engenhos; muitos 'índios' foram escravizados e outros tantos foram mortos. O reconhecimento identitário do professor em relação aos indígenas do período colonial é uma forma de "continuidad del pasado americano en el presente". ${ }^{8}$ Pois, segundo Rodolfo Kusch, ocorreu na América um processo de "fagocitación de lo blanco por lo indígena", ou seja, um englobamento do ser europeu pelo estar americano, de modo que o habitante desse continente mestiço permanece indígena em seu subsolo (Kusch, 2009, p.179).

Com base nas minhas observações em aula e na entrevista que realizei com o professor Lairton, pude constatar que ele possui conhecimento da tradição e de histórias kaingang - provavelmente por ter aprendido de seus pais e avós -, porém não consegue transformá-las em conteúdo escolar. Para ingressar esse tipo de conhecimento na escola é preciso antes reconhecer o valor que possui para então sistematizá-lo e dar a ele uma forma escolar. Esse trabalho só pode ser feito pelos próprios professores kaingang, e um lugar para fazer isso são os cursos de formação específica. Cursos de formação para professores indígenas vêm trabalhando nesse sentido, propondo reflexões que permitam aos professores-cursistas valorizarem os conhecimentos da cultura e que os incentivem a buscar saber mais junto à comunidade. Eles são necessários para potencializar o ensino de conhecimentos kaingang na escola e o desenvolvimento de processos próprios de aprendizagem dentro do espaço escolar.

O professor Lairton contou-me que quando consegue inserir elementos da história dos Kaingang em suas aulas, ele os traz principalmente de relatos que escutou: "Na verdade, quando eu faço alguns relatos em relação aos Kaingang, principalmente algumas análises que a gente vê, normalmente é por ouvir ... Do mesmo jeito que se faz uma pesquisa. Tu tens que ouvir para entender se é verdade ou não". Mas faz questão de salientar que muitos deles são 
confirmados por bibliografia - o que demonstra sua preocupação em ensinar algo referendado como conhecimento escolar. "Mas há relatos também em livros de historiadores ... Então aquilo que está escrito não está fugindo à realidade das coisas ... esse relato de universidades, de historiadores vem a confrontar e garantir mais que é verdade que isso existiu”. As palavras de Lairton demonstram uma mistura de verdades: as da oralidade e as da escrita. A ciência costuma levar em conta apenas a verdade registrada no papel, e a força disso é sentida na fala do professor que faz questão de afirmar que se podem comprovar os relatos orais na bibliografia. Mas ele também fala das histórias orais, dizendo que ouvi-las é como realizar uma pesquisa - o que nos leva a pensar na relação da escola com os velhos e as suas histórias.

\section{A ESCOLA E OS VELHOS NO ENSINO DA HISTÓRIA KAINGANG}

Se a história dos Kaingang é um tema apenas tangenciado na escola, como vimos, onde as crianças aprendem sobre o passado de seu povo? A primeira hipótese seria: ouvindo dos mais velhos. Os povos indígenas são sociedades que tradicionalmente transmitem os conhecimentos pela oralidade. Nessas sociedades orais há especialistas da memória, também chamados de guardiões da memória, que são, em geral, pessoas mais velhas da comunidade, mais vividas e, portanto, com mais conhecimento. Detentoras de saberes, elas são responsáveis por repassá-los às próximas gerações. ${ }^{9}$ No contexto atual de contato intenso com a sociedade nacional, em que a escrita já é uma realidade na vida dos povos indígenas brasileiros, em que a escola ocupa um papel central no dia a dia das comunidades, isso de fato acontece?

O jovem, a criança aprende muito de ouvir relatos, histórias de acontecimentos que já houve. Mas normalmente quando isso acontece é por causa de uma questão, talvez de um momento. Ele não está todo o dia com uma historinha lá para contar. É por momentos. Aconteceu tal fato, se acontece, alguém vem e diz "olha isso aconteceu há um tempo atrás, acontecia, ou é histórico, uma vez nós fazíamos assim" ... Por exemplo, no domingo à tarde passado, nós estávamos discutindo com esse mesmo que tu entrevistou, o Adelino da Rosa. Ele estava na minha casa e nós estávamos debatendo sobre a Guerra do Paraguai. (Lairton Melo, entrevista, 4 out. 2011) 
O fragmento da entrevista realizada com o professor Lairton revela que isso ainda acontece. Mas apenas 'por momentos'. Deitar à noite ao redor do fogo para ouvir histórias serem contadas pelos avós já não faz mais parte da rotina de jovens e crianças Kaingang. $\mathrm{O}$ fogo de chão está sendo substituído pelo fogão à lenha ou pelo fogão a gás. ${ }^{10}$ A longa jornada de trabalho muitas vezes não permite que isso aconteça. Em muitas famílias a televisão faz parte do cotidiano noturno. Em outras, esse espaço é ocupado pelo culto na igreja. Há também a falta de interesse das pessoas em buscar os velhos para ouvir seus relatos, embora eles ainda aconteçam, como o próprio professor Lairton comentou em seu depoimento.

Luís Emílio, velho sábio que mora em São João do Irapuá, outro setor da TI Guarita, contou-me em visita que lhe fiz que "muito poucos ainda contam histórias sentados ao redor do fogo". Explicou que isso não acontece mais como antigamente por causa das transformações no modo de viver dos Kaingang causadas pelo 'avanço do progresso'. Antes viviam da caça e da coleta e hoje vão ao mercado comprar os alimentos. Por essas palavras de Luís Emílio, pode-se reconhecer que frente à desordem trazida pelo Ocidente, imposta, mas também tomada por opção, a tradição kaingang se atualiza e se reordena tomando uma nova forma, que adota novidades mas conserva certos elementos fundamentais. ${ }^{11}$ Apesar das mudanças na vida dos Kaingang, "certos pais e avós ainda contam histórias para os filhos, para os netos, histórias dos bichos". O professor Lairton confirma que esse costume ainda é mantido, mesmo que em menor frequência e talvez revestido de outras formas, como se pode observar em mais um excerto da entrevista:

Eu acho que hoje, agora mesmo na atualidade, eu acho que a influência de outras coisas separou essa parte. Mas está sendo conservado ainda. E em determinados lugares bastante conservado. Principalmente pelas pessoas que são mais adultas. O jovem eu acho que está saindo, está indo um pouquinho mais para o lado das novidades ... Essa [a criança] participa ali. Essa está ali ainda. Agora o jovem, eu digo 13, 14, 15, 16 anos, ele já não está mais ali naquela convivência. Ele está se soltando mais para outras oportunidades que tem de participar. Mas eu acho que a parte mais adulta ainda permanece bastante. Não sei se tu notou quando tu caminhou pela nossa aldeia aqui, nosso setor, que ainda tem agrupamentos. Tem um ou dois sempre_conversando no local. Uma mulher fazendo uma trança de um balaio, um outro arranjo, mas alguém estava ali próximo daquilo ali. Nem que es- 
tiver só olhando, mas estava ali ... Se visitam bastante. Mas esse visitar já está do mesmo formato. Os mais adultos se visitam, mas os mais jovens já não está interessado muito nisso. Ele vai se interessar, mas as novidades atraem bastante. (Lairton Melo, entrevista, 4 out. 2011)

O professor Bruno parece mais cético quanto a isso. Ele pensa que as crianças não estão aprendendo histórias dos Kaingang fora da escola. Chegou a essa conclusão com base em uma atividade de aula sobre o panelão $o^{12}$ que tentou realizar com seus alunos do Pau Escrito, setor da TI Guarita onde é professor de História. "Eu disse: 'Podem perguntar para o pai de vocês, tentem saber com eles'. Só que quando trazem para discutirmos, não conseguem trazer nada. Os pais não estão contando isso para as crianças e eu, enquanto professor, não consigo avançar muito também”. É importante salientar que esse acontecimento foi muito traumático para os Kaingang e, considerando que a memória é seletiva e produzida desde o presente, muitas pessoas da comunidade talvez não queiram recordá-lo e por isso não contem histórias sobre esse tempo. Também é possível que a dificuldade esteja ligada à forma de condução da tarefa por parte do professor, ao modo que ele instrumentalizou os alunos para buscarem essas histórias em casa.

Se as gerações mais novas já não vivenciam essa contação de histórias, os adultos relatam que quando eram crianças esse espaço ainda era muito presente, o que demonstra que são as mudanças das últimas décadas que transformaram essa realidade. "Quando eu era pequeno, meu avô contava história para nós. Geralmente vinham os netos. Hoje não se faz isso mais. Dificilmente você vai chegar em uma casa de noite, vai estar lá um índio sentado, contando história para as crianças. Não vai achar isso acontecendo", relatou-me Bruno em entrevista. O professor Lairton conta com detalhes como eram essas noites na sua juventude.

quando os velhos se reuniam, eu lembro bem, com meu pai, com meus vizinhos que eram meus parentes, eles iam até a meia-noite conversando. Os adultos. E os mais pequeno corriam até umas horas e depois dormiam e ficavam. Ninguém estava preocupado com o outro dia. Se a gente era um pouquinho mais velho, já tinha uns 14, 15 anos, a gente ficava, antes de eles irem dormir, nós não ia dormir e ficávamos ouvindo as histórias deles. Mas normalmente, a turma maior não estava ali, tava brincando, tava fazendo alguma coisa fora disso aí, perto do fogo ... Mas 
quando surgia história nova, aí o grupo vinha. Se era a mesma história o grupo não vinha ... Nem que fosse uma mentira, mas ele vinha ali ... Tu me perguntou quando era isso, em que momento e onde. Onde seria, hoje está difícil, mas ainda tem, seria na casa de alguém, normalmente acontece na casa de um que tem um pouco mais de calma. Existe no povo Kaingang umas pessoas que sempre ficam ali, que eles sempre estão lá e as pessoas chegam lá por si ... Uma vez a gente chega lá e ele está lá, alguma coisa estão fazendo, se tiver uma comida para comer come, se não tiver está bom também. E ali essas coisas acontecem. (Lairton Melo, entrevista, 4 out. 2011)

Estas declarações mostram que atualmente o espaço para os velhos contarem histórias, assim como faziam no passado, está bastante reduzido e modificado. Levando em conta essa realidade e o fato de que são eles os principais detentores dos saberes tradicionais é que os documentos referentes à escola kaingang já previam uma relação dos velhos com a escola. Segundo o Regimento Coletivo das Escolas Estaduais Indígenas Kaingang, a metodologia de ensino-aprendizagem proposta para a escola kaingang "embasa-se no respeito à tradição oral das comunidades, valorizando o saber dos mais velhos e incentivando a que eles participem da escola relatando as histórias de seus antepassados - como era viver na terra indígena antigamente - para que, no decorrer do tempo, essas histórias sejam transmitidas de geração para geração, preservando a cultura kaingang". ${ }^{13}$ A Proposta Político-pedagógica de Referência das Escolas Indígenas Kaingang Estaduais do Rio Grande do Sul também é bastante clara quanto ao envolvimento das pessoas mais velhas da comunidade com a vida escolar. "Nas escolas indígenas, onde o trabalho com a língua kanhgág está sendo de forma restrita, o tempo das aulas deve ser aumentado para que o professor possa não só trabalhar a língua escrita, mas também possa ensinar os costumes, contar histórias e fazer visitas aos mais velhos". ${ }^{14}$ Andila Nivygsãnh Inácio, professora kaingang, em artigo sobre a educação escolar indígena, alerta seus colegas a esse respeito:

É preocupada com os professores indígenas que faço este trabalho porque, se eles quiserem ser bons professores kaingang, eles terão que ouvir os nossos 'velhos'! Pois é neles que está a essência da escola diferenciada. São, pois, a base para um Projeto Político-Pedagógico. O professor kaingang precisa resgatar e valorizar as formas tradicionais kaingang de repassar os conhecimentos para os jovens, por- 
que essas formas não são meros métodos em fase de experimentação, mas sim metodologias aplicadas, avaliadas e aperfeiçoadas através dos tempos. Saberes estes não disponíveis em nenhuma universidade, mas apenas, na memória dos nossos velhos, adormecida e anestesiada pelo sofrimento da discriminação e do preconceito de uma sociedade que não soube reconhecê-los. ${ }^{15}$

No entanto, quando perguntei aos professores de História se realizavam atividades em conjunto com os moradores mais velhos da comunidade, seja convidando para ir à escola, seja indo ao encontro deles, ambos me responderam negativamente. A conversa que tive com Adelino da Rosa, outro velho do setor do Irapuá que conhece as histórias kaingang, corrobora essa informação, pois ele não relatou a procura por parte de professores da escola local. Quando perguntei se o buscavam para ouvir histórias, Adelino contou que os alunos da Licenciatura Intercultural Indígena do Sul da Mata Atlântica (UFSC) que moram no Irapuá procuraram-no recentemente e agora estão realizando um trabalho conjunto estudantes-comunidade com base em um diálogo com os velhos. Isso mostra a importância dos cursos de formação específica para professores indígenas. Foi com base nas reflexões realizadas no curso, no entendimento do valor que possuem os saberes da oralidade, que os professores-cursistas perceberam a necessidade de se buscar com os velhos os conhecimentos tradicionais. Uma passagem do meu diário de campo ajuda a elucidar por que a escola não costuma fazer esse tipo de trabalho com os velhos:

$\mathrm{Na}$ aula de Valores Culturais o professor Lairton passou um vídeo que contava uma história de pescadores. Seu objetivo era mostrar que as histórias orais não são contadas exclusivamente em sociedades indígenas, mas também em comunidades de pescadores. Comentou com os alunos que eles poderiam ir falar com velhos para escutar histórias também. Quando acabou a aula, perguntei ao professor se ele pretendia pedir a algum velho que contasse uma história, ou convidando-o para ir à escola ou levando a turma até sua casa. Ele respondeu que é muito difícil fazer esse tipo de coisa. Disse que se fosse levar a turma para falar com a Vó Tonha [velha conhecedora dos remédios do mato], ela não ia dizer nada, porque ela acha que o professor, se é professor, tem que saber das coisas para ensinar. Disse que as pessoas têm medo do uso que a escola pode fazer dos seus conhecimentos. Ainda me deu outro exemplo. Se a Clair fosse pedir para alguém ensinar a fazer balaio, essa pessoa ia se recusar a ensinar, pois afinal a Clair é professora de Artesanato e deveria saber fazê-lo. (Diário de Campo, 27 set. 2011) 
Em primeiro lugar, é preciso salientar que há um descompasso cosmológico entre a escola, instituição característica do mundo ocidental, e o modo de vida kaingang. Embora seja comum a sociedade ocidental atual naturalizar e universalizar a existência da escola - atribuindo a ela a responsabilidade pela educação -, a escola tem uma história própria que precisa ser considerada para que se possa entendê-la. A escola começou a se constituir como a conhecemos hoje a partir do século XVI, quando do estabelecimento da Modernidade. Das transformações políticas, econômicas, sociais e culturais do período surgiram novas ideias e concepções que permitiram o surgimento dessa escola. De acordo com Varela e Álvarez-Uría, algumas dessas novidades foram: a definição de um estatuto de infância; a emergência de um espaço específico destinado à educação das crianças; o aparecimento de um corpo de especialistas da infância dotados de tecnologias específicas e de 'elaborados' códigos teóricos. ${ }^{16}$ Crianças foram colocadas em um lugar fechado, submetidas a diversos tipos de controle no espaço e no tempo, onde especialistas, denominados professores, passaram a transmitir determinados conhecimentos com base em certos métodos de ensino: "Essa maquinaria, além de inventar espaços específicos para a educação das crianças e dos jovens, foi decisiva para a invenção de saberes e seus respectivos especialistas, encarregados de dizer como educar, ensinar, vigiar e regular essas crianças e esses jovens". ${ }^{17}$

Nesse período, em que a Europa humanista enuncia os primeiros sinais do pensamento científico moderno, surge uma nova lógica de disciplina na sociedade - adotada e desenvolvida pela escola na sua plenitude. A escola constitui-se a partir de toda uma maquinaria que disciplinariza não só os corpos, mas também os saberes. Segundo Veiga-Neto, as disciplinas “são partições e repartições - de saberes e de comportamentos - que estabelecem campos especiais, específicos, de permissões e interdições, de modo que elas delimitam o que pode ser dito/pensado e feito ('contra' o que não pode ser dito/pensado e feito)" (Veiga-Neto, 2008, p.47). Ou seja, a escola atua normalizando as práticas e os saberes - determinando o que é normal e o que é anormal - de modo a homogeneizar as diferenças. No campo dos saberes, a escola seleciona os conhecimentos, definindo quais são os legítimos conteúdos escolares. Essa seleção baseia-se nas verdades da ciência e da razão, que ordenam e fragmentam os conhecimentos, transformando-os em temas escolares a serem trabalhados nas diferentes disciplinas que são transpostas para a escola. 
O povo kaingang, como outras sociedades tradicionais, possui seus próprios meios de produzir e transmitir os conhecimentos, num processo educacional baseado na oralidade que permeia a vida cotidiana das pessoas de modo integral. Possuem uma concepção de mundo unificada e totalizante, consideram a sociedade como um todo, em que a educação não se separa, espacial e temporalmente, das demais práticas. ${ }^{18} \mathrm{O}$ saber "é dividido a partir de graus de iniciação que o elevam, e não a partir de uma setorização de conhecimentos" (Balandier, 1997, p.156). No pensamento indígena não existe separação entre razão e emoção, ciência e intuição, e o saber refere-se "exclusivamente al hecho puro de vivir" (Kusch, 2009, p.320). Por isso, quanto mais tempo se vive, quanto mais velho se é, mais saber se tem acumulado. Além do velho sábio, outra figura importante na formação indígena é o xamã. Segundo Rodolfo Kusch, rito e saber mantêm uma estreita relação, pois por meio do ritual o saber é revelado ao xamã. A distância entre as cosmologias indígena e ocidental é definitivamente grande; portanto, por mais que os indígenas se apropriem da escola, ela sempre será portadora de outra concepção de mundo e, por isso, representará um espaço de conflito constante.

Outra questão que suscita o registro do diário de campo diz respeito ao limite de diálogo entre a escola e a comunidade. Essa dificuldade pode estar relacionada ao fato de a gestão escolar ser não indígena. A direção nas mãos de professoras 'brancas' distancia a escola da comunidade e, de certa maneira, representa uma barreira para a apropriação da escola por parte dos professores kaingang. A instituição escolar, em sua origem, já pertence a outra forma de estar no mundo; sob o comando dos não indígenas é provável que se mantenha o distanciamento em relação à comunidade, que continuará a vê-la como algo alheio a seu modo de vida, apesar de fazer parte de seu dia a dia. Acredito que, se a escola for pensada e administrada pelos próprios professores kaingang ou, pelo menos, em conjunto com eles -, será possível diminuir a distância entre os dois mundos, do ser europeu e do estar indígena. Quem sabe, assim, a escola poderá ser um lugar de encontro entre essas duas concepções, um lugar de fronteira, um verdadeiro espaço de interculturalidade que respeite os modos de ser indígenas e não um instrumento de ocidentalização, como em muitos aspectos ainda é.

Lairton também citou uma possível desconfiança das pessoas em relação à escola. Apesar de a maioria das pessoas com quem tive contato terem 
demonstrado estarem contentes com a escola, provavelmente existe certo receio quanto à instituição escolar, sobretudo dos mais velhos, que viveram um longo período de maus tratos e preconceito. O século XX, para o Kaingang, foi marcado pela vergonha de ser índio, de falar a sua língua, de realizar seus rituais, de ensinar os saberes ancestrais. Depois de muito tempo ouvindo que seu modo de vida e seus conhecimentos não tinham valor, ainda se percebe certa apreensão por parte das pessoas no trato com o que vem de fora, com o que é 'ocidental'. Pude perceber isso ao longo de minha pesquisa, certa desconfiança sobre os usos e destinos do meu trabalho - apesar de ter sido, de modo geral, bem recebida por todos.

Mais um ponto da fala do professor que merece reflexão é a ideia de que os professores - e a escola -, por possuírem um estatuto de sabedoria reconhecido pela sociedade (não indígena e também indígena), já detêm todos os conhecimentos. O velho Luís Emílio comprova a suspeita de Lairton de que os velhos se negariam a contar histórias e a ensinar determinados saberes kaingang aos professores por pensarem que eles já deveriam dominar esses assuntos: "Os professores têm que saber ensinar essas coisas". Ele considera importante que as crianças dominem as histórias kaingang, porém defende que “a história dos antigos tem que ser ensinada na escola" (grifos meus). Ele se posicionou contrário à ideia de os velhos irem à escola para contar histórias ou de os professores levarem os alunos à casa dos velhos. Aqui é importante destacar que a vida em sociedade para os Kaingang tem como valor fundamental a reciprocidade - o que leva a pensar que os velhos talvez não tenham interesse em fazer esse trabalho conjunto com as escolas porque não receberiam nada em troca. O prestígio e a remuneração ficariam com os professores. Então me pergunto: como os professores vão ensinar as histórias de antigamente na escola se eles não as conhecem? De alguma forma os professores têm que aprender essas histórias. Essa atitude de alguns velhos de transferir para a escola a responsabilidade pela transmissão dos saberes não seria resultado da perda de espaço que estariam sofrendo, certo ressentimento por estarem sendo 'substituídos' pelos professores? Afinal, como os professores indígenas, que ainda não são velhos, podem ter conhecimento para ensinar? Parece faltar uma peça nesse quebra-cabeça. Ou talvez continue faltando para sempre, pois as incompreensões entre os modos de vida indígenas (sem a escola) e não indígenas (criadores da escola) são inerentes à existência de uma escola indígena. 
Outra questão que pode ajudar a entender por que não ocorre um diálogo legítimo entre os velhos e a escola é a questão da língua, apontada pelo professor Bruno. Um ponto a se considerar é que as histórias são e existem em kaingang e, portanto, só possuem sentido pleno se contadas na língua nativa. Também é preciso notar que a maioria dos velhos, especialistas nessas histórias, têm o kaingang como língua materna e, por isso, compreendem e se comunicam melhor nesse idioma. Diante disso surgem as dificuldades: para conversar com um velho e conhecer as histórias é preciso falar ou pelo menos compreender kaingang.

E aí, quem sabe seja a dificuldade de estar contando essas histórias, dentro da escola kaingang, quem sabe a dificuldade seja o fato de o professor não falar a língua kaingang... Porque, quando eu vou conversar com as pessoas velhas, as pessoas mais de idade, para saber alguma coisa, eu preciso falar em kaingang com ele, não tem outra opção. Tenho que falar para que ele consiga me dizer as palavras mais adequadas para cada coisa, porque ele vai buscar na memória dele essas palavras, e na memória dele, essas palavras não estão traduzidas lá. Ele sabe do jeito que ele conseguiu armazenar na memória dele. Então, ele vai poder contar daquele jeito. Então, mesmo quando eu faço entrevista com os velhos, mesmo eu sendo Kaingang eu tenho dificuldade, porque tem muitas palavras que eles usam que eu não sei também. Então, isso dificulta o professor de História a fazer isso. (Bruno Ferreira, entrevistas, $1^{\circ}$ e 3 out. 2011)

A situação até agora descrita é de impasse: a escola não ensina as histórias kaingang e os velhos estão cada vez mais perdendo esse espaço na comunidade. O Regimento Coletivo das Escolas Estaduais Indígenas Kaingang (2003) e a Proposta Político-pedagógica de Referência das Escolas Indígenas Kaingang Estaduais do Rio Grande do Sul (2000) determinam que a escola kaingang deve instituir uma relação de diálogo intenso com as pessoas de mais idade e mais conhecimento na comunidade. No entanto, no presente momento pude constatar que isso não é uma realidade na escola Toldo Campinas. O professor de História da escola demonstra conhecer o que está estabelecido nos documentos e concorda com a ideia. Em entrevista perguntei: "Se a história dos Kaingang fosse ensinada na escola, o que aconteceria com o espaço dos velhos e das pessoas conhecedoras da comunidade? Se mantém, desaparece? Complementa o da escola?". 
Mas aí que a escola entra no processo. Acho que aí a escola tem que dar o espaço e oferecer essa oportunidade para que aquela pessoa que tem o conhecimento adquirido no viver de sua existência tenha a oportunidade de estar aqui. Ou tenha a oportunidade da escola estar lá ... eu acho também que a escola tem que ser melhor relatada do povo kaingang ... Na verdade, a escola tem que ajudar a dar um levante nisso e quem tem o conhecimento dizer "olha, nós éramos assim, fomos assim e seremos assim". (Lairton Melo, entrevista, 4 out. 2011)

"A escola tem que ajudar a dar um levante nisso" afirmou o professor Lairton. Nesse mesmo sentido pensa o professor Bruno. Para ele, o espaço dos velhos deve ser preservado na sua forma mais tradicional e a escola pode contribuir para isso. Bruno não acredita que o caminho para uma escola kaingang específica e diferenciada seja apenas levar os conhecimentos kaingang para dentro da escola, na forma de conteúdo escolar, como nas disciplinas de Artesanato e Valores Culturais, mas sim fazer uso de processos próprios de aprendizagem para ensinar as crianças - sem abrir mão da educação tradicional fora da escola. Conforme o professor Bruno, esse movimento de colocar sob responsabilidade da escola a transmissão desses conhecimentos faz que os saberes dos velhos percam valor, que essa forma de ensinar deixe de ter importância, na medida em que a escola já adquiriu um estatuto de "detentora dos conhecimentos verdadeiros" entre os índios. Para ele, a escola não pode assumir o lugar dos velhos da comunidade, ela deve mostrar que a história dos velhos também é verdadeira e não tem menos valor que a do livro. Ele considera que a escola indígena tem o papel de valorizar os saberes kaingang e, dessa forma, estimular que a criança busque-os com a comunidade. A função da escola "é ensinar você a buscar isso. E um velho, quando ele te conta, ele está te ensinando direto ali; a fonte é ele. E a escola está ensinando você a buscar essa fonte para que você saiba a partir dele”. De acordo com Bruno, do mesmo modo pode ser feito nas aulas de História: o professor pode encorajar seus alunos a buscarem as histórias kaingang com a comunidade.

A escola precisa de apossar um pouco dessas histórias para contar. Senão ela vai ficar sem memória, a comunidade, o povo aqui vai ficar sem memória. Se os velhos não contarem como surgiu essa vila aqui, as crianças não vão saber. E hoje você não consegue reunir as crianças na casa de um velho para contar ... Ela [a 
escola] poderia incentivar isso nas crianças, ou para que as crianças procurassem as pessoas, quisessem saber. (Bruno Ferreira, entrevista, 3 out. 2011)

Constatei em minha convivência na escola que temas kaingang não são objetos centrais de estudo nas aulas de História. No entanto, a etnografia permitiu descobrir que as histórias kaingang estão vivas. Tive a oportunidade de conhecer dois velhos, guardiões da memória, Luís Emílio e Adelino da Rosa, moradores do setor Irapuá, que me apresentaram a pontinha de um mundo rico em histórias. Que histórias são essas? Elas estão sendo transmitidas? Pode-se estabelecer alguma relação entre essas histórias e a escola? Antes de responder a essas perguntas é preciso refletir sobre o que é história. A concepção de história do professor Lairton é reveladora:

Eu acho que história é tudo aquilo que vive, mas história não está ali fixada em determinado lugar. Eu acho que ela se renova com o tempo. Acho que tudo é história, na verdade ... História, na verdade, é a vida da sociedade, é o que a sociedade é, é a história dela ... História do Kaingang é tudo aquilo que relata o Kaingang. É os contos, é as lendas. Ninguém fala história, por específico história, "História é isso do povo Kaingang". História para o povo Kaingang é os territórios, é as demarcações, é as ervas, é os medicamentos, é o casamento, tudo isso é história para o povo. É as lendas, os acontecimentos que houve, as guerras. Tudo isso é história. (Lairton Melo, entrevista, 4 out. 2011)

A descrição de Lairton do que seria história vai ao encontro do conceito de grande história de Rodolfo Kusch. Segundo o autor, essa é a história da humanidade, da sobrevivência da espécie humana desde o seu surgimento. Ela está em oposição à pequena história, aquela que começa a ser construída na Europa a partir da modernidade e que conta os feitos humanos. Nas palavras do autor,

Una forma más profunda de ver la historia sería dividirla en cambio entre la gran historia, que palpita detrás de los primeros utensilios hasta ahora y que dura lo que dura la especie, que simplemente está ahí, y la pequeña historia que relata sólo el acontecer puramente humano ocurrido en los últimos cuatrocientos años europeos, y es la de los que quieren ser alguien. (ibidem, p.153, grifos no original) 
Para Kusch, a pequena história é a história tal como se configurou no século XIX, sob a perspectiva do positivismo. É essa história que se inicia na Europa nos princípios da modernidade, que tem suas origens na cidade e que considera relevante só aquilo que favoreceu a cultura dinâmica e urbana, ou seja, remonta à Antiguidade Clássica, por reconhecer a herança cultural desses povos deixada para a civilização ocidental, e trata a Idade Média como um período de trevas a ser esquecido. A história que se crê ciência e classifica de Pré-História tudo aquilo que antecede o início das cidades, da escrita, do comércio. A história como disciplina escolar, que conta a evolução das elites que representam o ser no mundo, essa forma de viver que busca transformar e modificar o meio e a natureza. No caso da América, é a história que se inicia a partir da conquista europeia do continente e ignora o passado indígena milenar.

Já a grande história é a história da humanidade. Traça o itinerário real do homem porque não tem indivíduos (figuras de líderes e heróis), mas comunidades. Pensa o acontecer humano no plano da espécie e reduz os descobrimentos técnicos, as expansões e o poderio do homem a episódios menores. Responde à simples e muito profunda vivência humana em seu estar. É a história dos povos indígenas, dos povos tradicionais, dos operários, das massas. A grande história é a história do viver em comunidade, da conexão entre vida e natureza e de toda uma série de conceitos vitais que o Ocidente concretiza em termos demasiado limitados ou até exclui de sua perspectiva. Ela supõe muito mais elementos, porque representa o estar aqui indígena, que vive conectado com o meio e suas adversidades e por isso possui uma margem de possibilidades muito maior que a elite que, por sua vez, está conectada a sua cidade e a suas técnicas.

Buscando pensar um ensino de História diferenciado na escola kaingang, adoto o conceito de grande história, pois entendo que a história que é atualmente ensinada na escola, a do livro didático, é a história dita 'científica'. Ela se resume à pequena história e, por isso, exclui as narrativas do povo kaingang. De acordo com a professora kaingang Márcia Gojtẽn Nascimento existem pelo menos três tipos de narrativa na cultura kaingang:

Primeiro temos as denominadas gufã, que quer dizer ancestral. São narrativas que contam as origens, nos tempos ancestrais, e relatam fatos de tempos mais 
antigos. Dentro do gênero gufã temos também as fábulas. Temos também as narrativas chamadas ti si kãme que são as histórias antigas e verdadeiras. Outro gênero, que corresponde às narrativas engraçadas - inventadas, mentiras - é conhecido como venh ó. ${ }^{19}$

Em minhas visitas aos velhos do Irapuá, escutei diversas histórias - muitas do gênero gufã. Histórias da participação dos Kaingang na Guerra do Paraguai, na Revolução Federalista, na Revolução de 1923; do cacique Fongue; da criação do aldeamento Guarita; das guerras com os Kanhgág ju; ${ }^{20}$ da chegada dos padres; da criação da primeira escola em São João do Irapuá. Ouvi relatos do tempo em que os bichos falavam; do costume de enterrar o umbigo no lugar onde se nasce e depois voltar para morrer no mesmo local; do uso de remédios do mato pelo pai e pela mãe no nascimento dos filhos; de métodos anticoncepcionais tradicionais. Narrativas que poucos velhos ainda sabem e quase não se contam mais, nem em casa, nem na escola. Isso leva a certa preocupação por parte dos velhos, como nos disse Adelino: "Falta chegar mais próximo dos indígenas mais de idade, se entrosar com as pessoas que são mais de idade para buscar mais o conhecimento. Assim como vocês estão fazendo. Amanhã ou depois eu não estou aí. Morri, me fui. Mas alguém está aí para [contar]”. A seguir reproduzo minha versão de uma das histórias que escutei:

Tinha um macaco comendo milho. Mas um milho caiu por uma fresta dentro de um toco de árvore. O macaco tentou pegar, mas não conseguiu. Pediu para o toco e ele não lhe deu. Então disse que ia chamar o machado. Mas o machado não quis dar uma machadada no toco. Então disse que ia chamar o fogo. Mas o fogo não quis queimar o machado. Então disse que ia chamar a água para apagar o fogo. A água não quis ir apagar o fogo. Então disse que ia chamar o tigre para tomar a água. O tigre não quis ir tomar a água. Então ele disse que ia chamar o caçador. Aí o tigre foi atrás da água, a água foi atrás do fogo, o fogo foi atrás do machado e o machado cortou o toco ao meio e o macaco recuperou seu milho. (Luís Emílio, entrevista, 3 out. 2011)

Luís Emílio não consentiu que eu gravasse nossa conversa, por isso, tive de recorrer à minha memória, e assim escrevi a história do macaco. De acordo com a classificação das narrativas kaingang indicada por Márcia Nascimento, esse relato do tempo em que os bichos falavam se enquadraria no que ela chamou de gufã, pois é uma fábula dos tempos antigos. Um detalhe 
chama a atenção nessa história dos tempos antigos: a presença do machado. A incorporação dessa tecnologia ocidental à fábula, mostra que a tradição também é movimento: "Ela está dissociada da mera conformidade, da simples continuidade por invariância ou reprodução estrita das formas sociais e culturais; a tradição só age enquanto portadora de um dinamismo que lhe permite a adaptação..." (Balandier, 1997, p.38). Nesse processo, a tradição confere sentido ao novo e se reelabora. Essa narrativa do macaco possui uma continuidade que resiste ao acontecimento e dele se apropria. Jack Goody ${ }^{21}$ ao estudar os LoDagaa do Togo (África) descobriu que, após o contato com os europeus, eles passaram a situar o surgimento do ferro junto da criação da humanidade e da maioria dos elementos de sua cultura. As narrativas tradicionais sobrevivem de geração em geração, sempre sujeitas a novos fatos que geram adaptações e recriações.

Em conversa com o professor Bruno, ele revelou preocupação com as narrativas dos bichos que falavam. Apesar de não possuir um claro entendimento delas, pois na época em que as ouvia de seu pai não dava valor, acredita que elas tenham uma mensagem a passar e que os Kaingang devam buscar saber mais sobre tais histórias. Num primeiro momento em que conversamos sobre o assunto, ele afirmou pensar que esse tipo de narrativa não pertencia à dimensão da escola e que deveria ser contada pelos velhos no espaço familiar. No entanto, no decorrer da pesquisa, percebi que sua própria noção de história foi se transformando. Se a princípio ele defendia com veemência que a disciplina de História da escola indígena específica e diferenciada deveria ensinar a história dos Kaingang, incluindo-os na narração linear dos fatos que contam a construção do Brasil, com o tempo notei que ele já passava a enxergar todas essas narrativas kaingang com outros olhos, valorizando esse saber, mesmo que diferente da História com $\mathrm{H}$ maiúsculo. Se as discussões sobre o ensino de História na escola, propiciadas pela desordem que trouxe minha pesquisa no cotidiano da escola e do professor, levaram a uma mudança de perspectiva por parte de Bruno, penso que, se aos professores indígenas forem oportunizados momentos de reflexão (como nos cursos de formação), muita coisa pode mudar nesse movimento de construção da educação escolar indígena.

De modo geral, há pouco espaço destinado à transmissão das narrativas kaingang, tanto na escola como fora dela. Na escola Toldo Campinas predomina a pequena história e a narrativa do livro didático. O professor de História, no entanto, encontra algumas brechas onde consegue inserir algo do que já 
ouviu/viveu e mostrar que existe outra história, a kaingang, embora não se sinta plenamente autorizado para ensiná-la. Fora da escola, em casa, há pouco espaço para a transmissão das histórias kaingang e os velhos já não têm o mesmo valor de antigamente. Entretanto, minha pesquisa constatou que as histórias ainda estão vivas. Esse é o panorama que encontrei em minha etnografia. Como agir frente ao processo de ocidentalização que ainda atua através da escola indígena, fortalecendo a história oficial e encobrindo outras histórias e outras formas de narrar histórias? De que modo lutar para que as narrativas kaingang sobrevivam e sejam transmitidas às próximas gerações? Quem são os responsáveis por ensiná-las? Como fazer da escola uma aliada nesse empreendimento? Essas são perguntas sobre as quais os professores, os velhos e a comunidade kaingang juntos devem pensar. Precisam refletir sobre o papel da escola indígena que se propõe específica e diferenciada nesse desafio para a manutenção e a transmissão das histórias kaingang. "É preciso que se pense em estratégias para trazê-las de volta aos ouvidos dos mais jovens, para que se encantem nesse mundo onde o real e a magia seguem entrelaçados" (Nascimento, 2010, p.78).

\section{NOTAS}

${ }^{1}$ Censo Escolar da Educação Básica. MEC/Inep, 2011.

${ }^{2}$ FERREIRA, Mariana Kawall Leal. A educação escolar indígena: um diagnóstico crítico da situação no Brasil. In: SILVA, Aracy Lopes da; FERREIRA, Mariana Kawall Leal (Org.). Antropologia, História e Educação: a questão indígena e a escola. 2.ed. São Paulo: Global, 2001.

${ }^{3}$ BRASIL. Constituição da República Federativa do Brasil. Brasília, 1988. Art. 231 e Art. $210, \S 2^{\circ}$.

${ }^{4}$ BRASIL. Referencial Curricular Nacional para Escolas Indígenas. Brasília: MEC, 1998.

${ }^{5}$ GEERTZ, Clifford. A interpretação das culturas. Rio Janeiro: Livros Técnicos e Científicos Ed., 1989.

${ }^{6}$ Esses dados da Funasa estão publicados na página da internet do Instituto Socioambiental. INSTITUTO SOCIOMABIENTAL/POVOS INDÍGENAS NO BRASIL. Terra Indígena Guarita. Disponível em: ti.socioambiental.org/\#!/terras-indigenas/3680; Acesso em: 10 jul. 2011.

${ }^{7}$ RIO GRANDE DO SUL. Secretaria de Estado da Educação. Regimento Coletivo das Escolas Estaduais Indigenas Kaingang, 2003. p.5, grifos meus.

${ }^{8} \mathrm{KUSCH}$, Rodolfo. Obras completas. Rosário: Ed. Fundacion Ross, 2009. p.3. Rodolfo Kusch (1922-1979) foi um filósofo argentino que se dedicou a estudar a América na sua ances- 
tralidade, defendendo a existência de um pensamento ameríndio próprio com raízes no modo de estar no mundo característico do indígena americano.

${ }^{9}$ LE GOFF, Jacques. Memória. In: Enciclopédia Einaudi, v.1. Memória-História. Lisboa: Imprensa Nacional-Casa da Moeda, 1984.

${ }^{10}$ Em muitas casas já não é possível fazer fogo de chão, pois são construídas sobre um assoalho de madeira. Mas, como alternativa, a maioria dessas famílias possui um galpão ao lado de casa onde podem fazer o fogo na forma tradicional.

${ }^{11}$ BALANDIER, Georges. A desordem: elogio ao movimento. Rio de Janeiro: Bertrand Brasil, 1997.

${ }^{12}$ Panelão é o termo utilizado pelos Kaingang para se referirem ao sistema de exploração da mão de obra indígena imposto pelo Serviço de Proteção aos Índios.

${ }^{13}$ RIO GRANDE DO SUL. Secretaria de Estado da Educação. Regimento Coletivo das Escolas Estaduais Indígenas Kaingang, 2003. p.5, grifos meus.

${ }^{14}$ RIO GRANDE DO SUL. Secretaria de Estado da Educação. Proposta Político-Pedagógica de Referência das Escolas Indígenas Kaingang Estaduais do Rio Grande do Sul, 2000. p.3, grifos meus.

${ }^{15}$ INÁCIO, Andila Nivygsãnh. Venh Kanhrãn. In: BERGAMASCHI, Maria Aparecida; VENZON, Rodrigo Allegretti (Org.). Pensando a educação kaingang. Pelotas (RS): UFPEL, 2010. p.23.

${ }^{16}$ VARELA, Julia; ALVAREZ-URIA, Fernando. A maquinaria escolar. Revista Teoria \& Educação, Porto Alegre, n.6, p.68-96, 1992.

${ }^{17}$ VEIGA-NETO, Alfredo. Crise da modernidade e inovações curriculares: da disciplina para o controle. In: ENCONTRO NACIONAL DE DIDÁTICA E PRÁTICA DE ENSINO (ENDIPE), XIV. Anais... Porto Alegre, v.3, p.35-58 , 2008. p.40, grifos no original.

${ }^{18}$ BERGAMASCHI, Maria Aparecida. Nhembo'e. Enquanto o encanto permanece! Processos e práticas de escolarização nas aldeias Guarani. Tese (Doutorado) - Programa de Pós-Graduação em Educação, Universidade Federal do Rio Grande do Sul. Porto Alegre, 2005.

${ }^{19}$ NASCIMENTO, Márcia Gojtẽn. Ẽg vĩ ki kãmén sĩnvĩ han: as artes da palavra no kaigang. In: BERGAMASCHI, Maria Aparecida; VENZON, Rodrigo Allegretti (Org.). Pensando a educação kaingang. Pelotas: UFPEL, 2010. p.85.

${ }^{20}$ Kanhgág ju é o termo em kaingang para designar o povo Xokleng, inimigos históricos dos Kaingang.

${ }^{21}$ GOODY, Jack. O roubo da história: como os europeus se apropriaram das ideias e invenções do Oriente. São Paulo: Contexto, 2008.

Artigo recebido em 20 de junho de 2012. Aprovado em 1ํ de setembro de 2012. 